\title{
Toward a Trans-Scalar Peace System: Challenging Complex Global Conflict Systems
}

Gearoid Millar

Institute for Conflict, Transition, and Peace Research

University of Aberdeen

\begin{abstract}
Peacebuilding scholarship has not responded adequately to critiques of peacebuilding practice. This failure results from two related problems; an implicit assumption of a dichotomous relationship between conflict and peace, and an attendant failure to appreciate the challenges posed by complex global conflict systems. Stuck debating the dynamics of specific interventions in single states, the field has failed to fully appreciate how much conflict and peace are mutually constitutive across contexts and how underlying legitimating logics driving contemporary conflict transcend borders and reach across scales. Therefore, this paper argues, we must fully accept a more nuanced, trans-national, and trans-scalar conception of how conflict and peace are interrelated within states, internationally, and globally. The goal of the paper, therefore, is to tie together disparate arguments within the field to encourage new thinking regarding peacebuilding and more a holistic conception of a trans-scalar global peace system to replace the prevailing global conflict system.
\end{abstract}

\section{Keywords:}

Conflict; Peacebuilding; Peace Systems; Trans-Scalar; Complexity Theory

\section{Introduction}

The past decade has been one of stark contrasts for the field of peacebuilding. On one hand, the practical side of the 'peace industry' has never been more in demand. ${ }^{1}$ From the mid-1990s to the mid-2000s, the field developed into a substantial area of theory, policy and practice and became deeply interwoven with the practices of post-conflict security, transitional justice, development, and economic reform. ${ }^{2}$ However, since the mid-2000s scholarship regarding peacebuilding intervention has also become largely divided between its supporters and its critics. In the former camp are those who generally support the 'liberal peace' model based on a strong state, robust legal and political

\footnotetext{
${ }^{1}$ Roger Mac Ginty, 'Routine peace: Technocracy and peacebuilding', Cooperation and Conflict 47, no. 3 (2012): 289.

${ }^{2}$ See Peter Uvin, 'The Development/Peacebuilding Nexus: A Typology and History of Changing Paradigms', Journal of Peacebuilding \& Development 1, no. 1 (2002): 5-24; Necla Tschirgi, Peacebuilding as the Link between Security and Development: Is the Window of Opportunity Closing? (New York, NY: International Peace Academy, 2003); Keith Krause and Oiver Jütersonke, 'Peace, Security and Development in Post-Conflict Environments', Security Dialogue 36, no. 4 (2005): 447-62.
} 
institutions and free-market economic reforms. ${ }^{3}$ In the latter camp are those who decry the imposition of such mechanisms in post-conflict societies. ${ }^{4}$

There are many elements to this critical camp. There are those who argue that peacebuilding lacks local ownership and buy-in, ${ }^{5}$ others who critique its application of 'tool-kit' mechanisms, ${ }^{6}$ yet others who lament the general dominance of technocratic solutions, ${ }^{7}$ and still others who are concerned about the power of the technocrats themselves. ${ }^{8}$ Such weaknesses are surely among the root problems driving the practical, social, and cultural disconnect many scholars identify between peace interventions and those living in post-conflict societies today. ${ }^{9}$ These critiques are well versed, founded on the now clear evidence that peacebuilding often does not build peace, ${ }^{10}$ and have inspired efforts to find solutions for these problems, such as the many 'turns' in the literature; to

\footnotetext{
${ }^{3}$ Michael W. Doyle, 'Three Pillars of the Liberal Peace', The American Political Science Review 99, no. 3 (2005): 463-66; Roland Paris, 'Saving Liberal Peacebuilding,' Review of International Studies 36, no. 2 (2010): 337-65.

${ }^{4}$ Susanna Campbell, David Chandler and Meera Sabaratnam, eds., A Liberal Peace? The Problems and Practices of Peacebuilding (London: Zed Books, 2011); Roger Mac Ginty and Oliver P. Richmond, 'The Local Turn in Peace Building: A Critical Agenda for Peace', Third World Quarterly 34, no. 5 (2013): 763-83; Michael Pugh, Neil Cooper and Mandy Turner, 'Introduction,' in Whose Peace? Critical Perspectives on the Political Economy of Peacebuilding, ed. Michael Pugh, Neil Cooper and Many Turner (New York, NY: Palgrave MacMillan, 2011), 110.

${ }^{5}$ Timothy Donais, 'Empowerment or Imposition? Dilemmas of Local Ownership in Post-Conflict Peacebuilding Processes. Peace \& Change 34, no. 1 (2009): 3-26; Timothy Donais, Peacebuilding and Local Ownership: PostConflict Consensus-Building (New York, NY: Routledge, 2012); Sung Yong Lee and Alpaslan Özerdem, Local Ownership in International Peacebuilding: Key Theoretical and Practical Issues (London: Routledge, 2015). ${ }^{6}$ Rosalind Shaw, Rethinking Truth and Reconciliation Commissions: Lessons from Sierra Leone. Report \#130 (United States Institute of Peace, 2005) http://www.usip.org/sites/default/files/sr130.pdf (accessed October 12, 2018); Charles T. Call and Elizabeth M. Cousens, 'Ending Wars and Building Peace: International Responses to War-Torn Societies', International Studies Perspectives 9, no. 1 (2008): 14.

${ }^{7}$ Laurant Goetschel and Tobias Hagmann, 'Civilian Peacebuilding: Peace by Bureaucratic Means?', Conflict, Security and Development 9, no. 1 (2009): 55-73; Roger Mac Ginty, 'Hybrid peace: The interaction between top-down and bottom-up peace,' Security Dialogue 41, no. 4 (2010): 391-412.

${ }^{8}$ Ole Jacob Sending, Why Peacebuilders Fail to Secure Ownership and be Sensitive to Context. Working Paper 755 (Norwegian Institute for International Affairs, 2009) https://brage.bibsys.no/xmlui/bitstream/handle/11250/277766/SIP-1-WP-755-Sending.pdf?sequence=3 (accessed October 12, 2018); Janine Natalya Clark, 'UN Peacekeeping in the Democratic Republic of Congo: Reflections on MONUSCO and its Contradictory Mandate', Journal of International Peacekeeping 15, no. 3-4 (2011): 363-83; Theo Neethling, 'From MONUC to MONUSCO and Beyond: Prospects for Reconstruction, StateBuilding and Security Governance in the DRC', South African Journal of International Affairs 18, no. 1 (2011: 234; Severine Autesserre, Peaceland: Conflict Resolution and the Everyday Politics of International Intervention. (New York, NY: Cambridge University Press, 2014), 116.

${ }^{9}$ Shaw, 'Rethinking Truth and Reconciliation'; Donais, 'Empowerment or Imposition'; Rosalind Shaw, Lars Waldorf, and Pierre Hazan, Localizing Transitional Justice: Interventions and Priorities after Mass Violence. (Stanford, CA: Stanford University Press, 2010); Gearoid Millar, 'Local Evaluations of Truth Telling in Sierra Leone: Getting at 'Why' Though a Qualitative Case Study Analysis', International Journal of Transitional Justice 4, no. 4 (2010): 477-96; Oliver P. Richmond, 'Beyond Local Ownership in the Architecture of International Peacebuilding', Ethnopolitics 11, no. 4 (2012): 354-75.

${ }^{10}$ Tobias Denskus, 'Peacebuilding Does Not Build Peace', Development in Practice 17, no. 4-5 (2007): 656-62.
} 
emancipation, ${ }^{11}$ to resistance, ${ }^{12}$ to hybridity, ${ }^{13}$ to 'the local',${ }^{14}$ and to 'the everyday'.${ }^{15}$ These various (and related) interjections have provided powerful theoretical lenses by which to interpret the many empirical verifications of peacebuilding's failures over the past twenty years. They have also each examined previously undertheorized interactions and power dynamics across scales - the global, regional, international, and local - and therefore built the foundation on which this paper builds.

However, they also serve as its point of departure, because while these contributions have focused our attention on a progressively more micro-perspective - evermore within the state, the society, the culture, the local, and the everyday - this paper's contribution lies in its effort to merge this inward focus with a more robust recognition of the broader structures and global features of complex conflict systems. This is not to allege that scholars writing in the above traditions are unaware of these dynamics, as indeed the most recent discussions of 'friction' and 'scalar' politics evidence precisely such an awareness. ${ }^{16}$ But it is instead to note that even these approaches are limited as their focus has been on interactions across scales, but only within specific cases of post-conflict intervention; how the global, regional, national and local interact within a given state. As such, they fail to address the more complex manner in which conflict and peace are mutually constitutive both within and across states and are insufficiently equipped to perceive, understand, and suggest solutions for overcoming the globally structured nature of contemporary conflict. This paper, therefore, ties

\footnotetext{
${ }^{11}$ Oliver P. Richmond, 'Patterns of peace', Global Society 20, no. 4 (2006): 367-94; Chuck Theissen, 'Emancipatory Peacebuilding: Critical Responses to (Neo)Liberal Trends', in Critical Issues in Peace and Conflict Studies: Theory, Practice, and Pedagogy, ed. Thomas Matyók, Jessica Senehi, and Sean Byrne (Lanham, MD: Lexington Books, 2011), 115-40; Roddy Brett and Lina Malagon, 'Overcoming the Original Sin of the "Original Condition": How Reparations May Contribute to Emancipatory Peacebuilding', Human Rights Review 14, no. 3 (2013): 257-71; Hanna Leonardsson and Gustav Rudd, 'The "Local Turn" in Peacebuilding: A Literature Review of Effective and Emancipatory Local Peacebuilding', Third World Quarterly 36, no. 5 (2015): 825-39.

${ }^{12}$ Roger Mac Ginty, International Peacebuilding and Local Resistance: Hybrid Forms of Peace (New York, NY: Palgrave MacMillan, 2011); Steffanie Kappler and Oliver P. Richmond, 'Peacebuilding and Culture in Bosnia and Herzegovina: Resistance or Emancipation?', Security Dialogue 42, no. 3 (2011): 261-78.

${ }^{13}$ Mac Ginty, 'Hybrid Peace'; Roberto Belloni, 'Hybrid Peace Governance: Its Emergence and Significance', Global Governance 18, no. 1 (2012): 21-38; Gearoid Millar, 'Disaggregating Hybridity: Why Hybrid Institutions do not Produce Predictable Experiences of Peace. Journal of Peace Research 51, no. 4 (2014): 501-14.

${ }^{14}$ Mac Ginty and Richmond, 'The Local Turn'; Thania Paffenholz, 'Unpacking the Local Turn in Peacebuilding: A Critical Assessment towards an Agenda for Future Research', Third World Quarterly 36, no. 5 (2015): 857-74; Elisa Randazzo, 'The Paradoxes of the 'Everyday': Scrutinising the Local Turn in Peace Building', Third World Quarterly 37, no. 8 (2016): 1351-70.

${ }^{15}$ Oliver P. Richmond, 'Becoming Liberal, Unbecoming Liberalism: Liberal-Local Hybridity via the Everyday as a Response to the Paradoxes of Liberal Peacebuilding', Journal of Intervention and Statebuilding 3, no. 3 (2009): 324-44; Oliver P. Richmond and Audra Mitchell, eds., Hybrid Forms of Peace: From Everyday Agency to PostLiberalism (Basingstoke: Palgrave Macmillan, 2011); Also see contributions to: Annika Björkdahl, Martin Hall and Ted Svensson, 'Everyday International Relations: Editors Introduction', Cooperation and Conflict 54, no. 2 (2019): 123-130; Helen Berents \& Siophan McEvoy-Levy, 'Theorising Youth and Everyday Peacebuilding', Peacebuilding 3, no. 2 (2015): 115-125.

${ }^{16}$ See Annika Björkdahl, Kristine Höglund, Gearoid Millar, Jair Van der Lijn, and Willemijn Verkoren, Peacebuilding and Friction: Global and Local Encounters in Post Conflict Societies (London: Routledge, 2016); Shahar Hameiri and Lee Jones, 'Beyond Hybridity to the Politics of Scale: International Intervention and "Local" politics', Development and Change 48, no. 1 (2017): 54-77.
} 
together existing arguments within the field to encourage new thinking regarding peacebuilding and more holistic conceptions of a trans-scalar global peace system.

Section one of this paper describes the co-existence and mutual enforcement of violence and peace within states. Section two then extends this to describe similar dynamics between states, and proceeds to illustrate this by discussing the existing literature on war economies. Section three then describes how this inter-dependence is both structured by and re-constitutive of complex systems at macro scales which bind together violence and peace in the contemporary era of globalization. This section presents core elements of complexity theory and highlights the importance of understanding the inter-dependence of violence and peace as symptomatic of a complex adaptive system which today spans the globe, particularly focusing on the undergirding legitimating logics which sustain this system. Finally, the last section presents four specific ideas for how we can maintain our ambitions towards peacebuilding while fulfilling the goals of the local turn by working to deconstruct the present system built on the mutual dependence of violence and peace, and promote alternative legitimating logics that may instead provide the foundation for a trans-scalar peace system.

\section{The False Dichotomy between Conflict and Peace}

As noted recently by Pain, "[w]ar has predominantly been theorised by mainstream scholars" ... "as a phenomenon that is spatially, socially and politically separate from intimate" or domestic violence. ${ }^{17}$ Consistent with this, in both mainstream academic discourse and popular culture, peace and conflict are usually considered distinct phenomena. Peace is considered a state of equilibrium and conflict as a disruption of that norm; as an "exceptional event". ${ }^{18}$ In novels and films, for example, popular culture presents a narrative in which peaceful societies are disrupted and individuals are uprooted from peaceful lives among family and friends by violent events and forced to engage in violent conflict. In such narratives violence and conflict are either elsewhere or, when 'at home', depicted as limited to a distinct period of time. ${ }^{19}$ It is not inconsequential that we quite commonly call these 'peace-time' and 'war-time'; in common parlance and common sense they are separate and explicitly distinct temporalities. ${ }^{20}$ But as more recent scholarship argues, this perception is incorrect. ${ }^{21}$ Contrary to what

\footnotetext{
${ }^{17}$ Rachel Pain, 'Intimate War', Political Geography 44 (2015): 66.

${ }^{18}$ Roger Mac Ginty, 'Circuits, The Everyday and International Relations: Connecting the Home to the International and Transnational', Cooperation and Conflict 54, no. 2 (2019): 237.

${ }^{19}$ See Yuval Bensiman, "'Mom, I'm Home": Israeli Labanon-War Films as Inadvertent Preservers of the National Narrative,' Israel Studies 18, no. 3 (2013): 112-132;

${ }^{20}$ Mary L. Dudziak, War-Time: An Idea, Its History, Its Consequences (Oxford: Oxford University Press, 2012): 16.

${ }^{21}$ Pain, 'Intimate War'; Robin Luckham, 'Whose Violence, Whose Security? Can Violence Reduction and Security Work for Poor, Excluded and Vulnerable People?', Peacebuilding 5, no. 2 (2017): 99-117.
} 
mainstream academic discourse and popular culture tell us, there is little question today that conflict and peace are in fact conjoined, dependent, mutually constitutive, or "entwined". ${ }^{22}$

Such an argument, regarding the co-constitution and mutual dependence of violence and conflict within states, is dependent on Galtung's typology of violence, with which most readers will be familiar. ${ }^{23}$ This typology provides for a subtle and multiple conception of violence as distinct from the simple violation of another's physical integrity via the application of force (direct violence), and recognizes how historical structures within the social order may give rise to detrimental inequalities between individuals and groups (indirect violence), and the ideational or normative paradigms, or privileged logics, which may legitimate either of the other two forms (cultural violence). This disaggregated conception of violence is related, of course, to Galtung's conception of negative and positive peace, with the former only reliant on the absence of direct violence, while the latter requires also the absence of indirect and cultural violence. ${ }^{24} \mathrm{My}$ approach here is consistent with these more subtle definitions of violence and peace, and conflict as discussed here is not purely defined by direct violence (explicit conflict), but also by indirect and cultural violence (implicit conflict).

In any state we might think of as peaceful, therefore, there are multiple, ingrained, and usually endemic conflicts of varying kinds (direct, indirect, and cultural) ongoing to varying degrees (implicit and explicit). Indeed, it is often forgotten that the very institutions we consider as the central pillars of such states - those of politics (democratic governance and elections), liberal economics (free markets and trade), and law (constitutions, courts, and legislatures) ${ }^{25}$ - are themselves mechanisms for the management (but not the avoidance or resolution) of conflict. Conflict management, therefore, is central to the operation of the state because conflict is central to society and to social interaction itself; individuals and social groups endlessly compete and cooperate over all the things we might possibly choose to value, exchange and consume. Conflict, therefore, is inevitable, although it need not be destructive. ${ }^{26}$ This is particularly true within societies which try to protect citizens from direct violence and to ensure relatively low levels of indirect and cultural violence (such as in many wealthy states of the Global North). Substantial problems arise, however, in states we might today define as failed, fragile, weak or 'developing', which are far more likely to play host to endemic violence; direct, indirect, and cultural. In such societies the security, peace, and opulence of a minority is often achieved only at the expense of insecurity and violence among the rest. ${ }^{27}$

\footnotetext{
${ }^{22}$ See Louise Wiuff Moe, 'The Strange Wars of Liberal Peace: Hybridity, Complexity and the Governing Rationalities of Counterinsurgency in Somalia,' Peacebuilding 4, no. 1 (2016): 116. See also Richard Jackson, 'Post-Liberal Peacebuilding and the Pacifist State', Peacebuilding 6, no 1 (2018): 1-16.

${ }^{23}$ Johan Galung, 'Violence, Peace, and Peace Research', Journal of Peace Research 6, no. 3 (1969): 167-191

${ }^{24}$ Ibid, 2.

${ }^{25}$ Doyle, 'Three Pillars'.

${ }^{26}$ Louis Kriesberg, Constructive Conflicts: From Escalation to Resolution (Lanham, MD: Roman and Littlefield, 1998).

${ }^{27}$ See Severine Autesserre, 'The Responsibility to Protect in Congo: The Failure of Grassroots Prevention', International Peacekeeping 23, no. 1 (2016): 29-51; Roderic Alley, 'Regimes that Obstruct: A Problem of
} 
Sierra Leone is one very good case illustrating such dynamics. Traditionally structured around the patron-client relationships between 'Big Men' who control resources (wealth and land) and small men who exchange their support (in politics and labour) for the protection of the former, this is a society in which disparities of wealth and status are central to social life. ${ }^{28}$ However, in the period immediately preceding the outbreak of the 1991-2002 war, the reciprocal exchange assumed to bind together the 'Big Men' and the small broke down. Throughout the 1970s and 80s the patrimonial elite became increasingly corrupt and rapacious, expropriating more and more of the nation's vast resource wealth, ${ }^{29}$ until eventually they were unable to provide the resources those beneath them expected in exchange for political support and labour. ${ }^{30}$ The wealth and privileges controlled by the minority, secure in their compounds and with access to quality education and healthcare in the capital or overseas, contrasted starkly to the complete deterioration of such services for the common people, who lived in a progressively worsening situation of poverty. In such an environment, where the indirect violence of inequality degrades the institutions and infrastructure of the state many of the marginalized and underprivileged found direct violence their only recourse. ${ }^{31}$ War eventually arrived in 1991, but long before it violence and peace had lived side by side, even if unequally distributed.

And this is where the dynamics within specific states can be clearly and directly related to those between states. Indeed, this is even true in the hyper-globalization of the post-Cold War period. As the logic of open markets and the financialization of resources have come to dominate international order, ${ }^{32}$ and communications and transportation technology have opened nearly every corner of the world up to exploitation and the penetration of capital, ${ }^{33}$ the world has been knit evermore closely together by logistical supply chains and economic interdependence. While

\footnotetext{
Institutional Reburbishment Following Internal Conflict', Journal of Intervention and Statebuilding 9, no. 1 (2015): 112-133; Mariana dos Santos Parra, 'Minustah's Legitimacy and the 'Security First' Approach: Reassessing Statebuilding and its Violent Features in the Case of Haiti', Journal of Intervention and Statebuilding (2019) Online First: DOI 10.1080/17502977.2018.1558801.

${ }^{28}$ Catherine E. Bolton, I did it to Save My Life: Love and Survival in Sierra Leone (Berkeley, CA: University of California Press, 2012).

${ }^{29}$ Paul Richards, Fighting for the Rainforest: War, Youth and Resources in Sierra Leone (Portsmouth: Heinemann, 1996).

${ }^{30}$ William Reno, 'War, Markets, and the Reconfiguration of West Africa's Weak States', Comparative Politics 29, no. 4 (1997): 493-510; Sahr Kpundeh, 'Corruption and Political Insurgency in Sierra Leone', in Between Democracy and Terror: The Sierra Leone Civil War, ed. Ibrahim Abdullah (Dakar: Council for the Development of Social Science Research in Africa, 2004), 90-103.

${ }^{31}$ Patrick K. Muana, 'The Kamajoi Militia: Violence, Internal Displacement and the Politics of CounterInsurgency', African Development 22, no. 3/4 (1997): 77-100; Ibrahim Abdullah, 'Bush Path to Destruction: The Origin and Character of the Revolutionary United Front/Sierra Leone', The Journal of Modern African Studies 36, no. 2 (1998): 203-35; Richard Fanthorpe, 'On the Limits of Liberal Peace: Chiefs and Democratic Decentralization in Post-War Sierra Leone', African Affairs 105, no. 418 (2006): 27-49.

32 Jan Selby, 'The Political Economy of Peace Processes,' in Whose Peace? Critical Perspectives on the Political Economy of Peacebuilding, ed. Michael Pugh, Neil Cooper, and Mandy Turner (New York, NY: Palgrave MacMillan, 2008), 19.

${ }^{33}$ Saskia Sassen, Territory, Authority, Rights: From Medieval to Global Assemblages (Princeton, NJ: Princeton University Press, 2006).
} 
institutions such as the World Trade Organization (WTO), International Monetary Fund (IMF), and World Bank function to some extent as governing bodies astride this new global system, global governance is still relatively weak and multi-national corporations operate in a relatively anarchic international market which resembles much more a weak state than it does a strong democracy. As a result, while inter-group conflicts are restrained and largely limited to milder forms of indirect and cultural violence in strong states (for example, Iceland, New Zealand, or Finland), at the global scale indirect and cultural violence run rampant. This leads far too often, as will be discussed now, to direct inter-group violence and explicit conflict at the local and sub-state level.

\section{Global Conflict Systems}

While this may seem an extreme claim to make, the evidence has been mounting for some time that the global domination of neo-liberal and free market oriented capitalism is leading more to violence (both direct and indirect) and explicit conflict than it is to the interdependence induced peace initially theorized by Wilsonian peace thinkers. ${ }^{34}$ A great amount of literature has evidenced this in the past 20 years. Early influential works on the topic include Kaplan's now apocryphal description of an emerging "criminal anarchy" that would consume much of the developing world, ${ }^{35}$ which was followed quickly by Kaldor's more nuanced description of "New Wars" motivated by "new identity politics" ${ }^{36}$ which has, over the years, evolved to focus more on the economic motivation or modes of finance for conflict actors. ${ }^{37}$ Similarly, a debate initiated by Collier and Hoeffler's controversial argument regarding the role of greed over grievance in motivating conflict, ${ }^{38}$ although recognized later as overly simplistic ${ }^{39}$ nonetheless spurred a substantial amount of work examining the link between economic motivations, political grievances, and incidents of conflict. ${ }^{40}$

\footnotetext{
${ }^{34}$ Wolfgang J. Helbich, 'American Liberals in the League of Nations Controversy. The Public Opinion Quarterly 31, no. 4 (1967-1968): 568-596.

${ }^{35}$ Robert D. Kaplan, 'The Coming Anarchy: How Scarcity, Crime, Overpopulation, Tribalism, and Disease are Rapidly Destroying the Social Fabric of our Planet', The Atlantic Monthly 273, no. 2 (1994): 44-65.

${ }^{36}$ Mary Kaldor, New and Old Wars: Organized Violence in a Global Era (Stanford, CA: Stanford University Press, 1999).

${ }^{37}$ Mary Kaldor, New and Old Wars: Organized Violence in a Global Era (3rd Edition), (Cambridge: Polity Press, 2012).

38 Paul Collier and Anke Hoeffler, 'On the Economic Causes of Civil War', Oxford Economic Papers 50, no. 4 (1998): 563-573; Paul Collier and Anke Hoeffler, 'Greed and Grievance in Civil War. Oxford Economic Papers 56, no. 4 (2004): 563-595.

39 Paul Collier, Anke Hoeffler, and Dominic Rohner, 'Beyond Greed and Grievance: Feasibility and Civil War', Oxford Economic Papers 61, no. 1 (2009): 1-27.

${ }^{40}$ See Mats Berdal and David M. Malone, Greed and Grievance: Economic Agendas in Civil War (Boulder, CO: Lynne Rienner Publishers, 2000); Karen Ballentine and Jake Sherman, 'Introduction', in The Political Economy of Armed Conflict: Beyond Greed and Grievance, ed. Karen Ballentine and Jake Sherman (Boulder, CO: Lynne Rienner Publishers, 2003), 1-15; Karen Ballentine and Heiko Nitzschke, Profiting from Peace: Managing the Resource Dimensions of Civil War (Boulder, CO: Lynne Rienner Publishers, 2005).
} 
This field of work, perhaps best captured under the "war economies" label, ${ }^{41}$ has greatly influenced theories regarding conflict within states. This includes work on the "resource curse", ${ }^{2}$ which posits that dependence on a limited number of exports raises a state's likelihood of experiencing violent conflict, as well as literature on the tendency for such countries to lean towards authoritarianism due to reliance on rents from resource extraction instead of taxes from citizenry. ${ }^{43}$ Clearly, however, the importance of resources is primarily based not on their value within a state, but on a broader market. There is no point in controlling resources within most failed, weak, fragile or developing countries; the real profit lies elsewhere. It is for this reason that "war economies" are always internationalized, regional, or even global. Indeed, many have described how resources are shipped across borders in the context of conflict, such as in Afghanistan,${ }^{44}$ Colombia, ${ }^{45}$ or the Democratic Republic of Congo, ${ }^{46}$ and even these examples present a restricted impression of the global market forces which have driven such processes. ${ }^{47}$

A thorough picture does not see opium from Afghanistan as simply moving across borders into Pakistan, Iran and Tajikistan, but also as the subject of investment and planting in Afghanistan specifically because of global market prices and, of course, because it is ultimately destined for consumption in the West. ${ }^{48}$ The same is true with almost all such conflict resources; whether oil in Angola or Cocaine in Colombia, Timber in Liberia or Coltan in the DRC. The demand and, therefore, the value for such commodities is always elsewhere, and it is only this value to those in prosperous countries which can imbue the commodity with its "curse". Sierra Leone, again, presents a classic case in the apparent role alluvial diamonds played in prolonging that war. ${ }^{49}$ There is no value to a hard, shiny stone when one is hungry and thirsty. However, value is imbued to these shimmering little

\footnotetext{
${ }^{41}$ Michael Pugh, Neil Cooper and Jonathan Goodhand, War Economies in a Regional Context: Challenges and Transformation (Boulder, CO: Lynne Rienner Publishers, 2004).

42 James D. Fearon, 'Primary Commodity Exports and Civil War. Journal of Conflict Resolution 49, no. 4 (2005): 483-507; Michael Ross, 'What Have we Learned about the Resource Curse?' Annual Review of Political Science 18 (2015): 239-259; Jędrzej George Frynas, Geoffrey Wood and Rimothy Hinks, 'The Resource Curse Without Natural Resources: Expectations of Resource Booms and Their Impact', African Affairs 116, no. 463 (): $233-260$. ${ }^{43}$ Paul Collier and Anke Hoeffler, 'Resource Rents, Governance, and Conflict', Journal of Conflict Resolution 49, no. 4 (2005): 625-33.

44 Jonathan Goodhand, 'Frontiers and Wars: The Opium Economy in Afghanistan', Journal of Agrarian Change 5, no. 2 (2005): 191-216.

${ }^{45}$ Thad Dunning and Leslie Wirpsa, 'Oil and the Political Economy of Conflict in Colombia and Beyond: A Linkages Approach', Geopolitics 9, no. 1 (2010): 81-108.

${ }^{46}$ Dena Montague, 'Stolen Goods: Coltan and Conflict in the Democratic Republic of Congo', SAIS Review 22, no. 1 (2002): 103-18.

${ }^{47}$ Matthew T. Huber, 'Enforcing Scarcity: Oil, Violence, and the Making of the Market', Annals of the Association of American Geographers 101, no. 4 (2011): 816-26; Amber Huff Understanding Relationships between the Green Economy, Resource Financialization and Conflict. IDS Policy Briefing \#95 (Brighton: Institute for Development Studies, 2015).

${ }^{48}$ Hermann Kreutzmann, 'Afghanistan and the Opium World Market: Poppy Production and Trade', Iranian Studies 40, no. 5 (2007): 605-21.

${ }^{49}$ Lucinda Saunders, 'Rich and Rare are the Gems They War: Holding De Beers Accountable for Trading Conflict Diamonds. Fordham International Law Journal 24 (2000): 1402-76; John L. Hirsch, Sierra Leone: Diamonds and the Struggle for Democracy (Boulder, CO: Lynne Rienner Publishers, 2001).
} 
rocks when more affluent individuals covet them as decorations, as jewellery, as heirlooms, or for pure financial speculation. It is only this value on the global market that endows them with their curse; the power to motivate violence and conflict, to spur "war lords" to use violence to acquire and control mining sites and then manipulate and control slave labour for the acquisition and eventual export of those resources. ${ }^{50}$

But this should be recognized as only the transition from implicit conflict to explicit conflict and from indirect to direct violence, as the violence of the situation is always endemic in the massive inequalities that become apparent in a world being knit every more closely together into one market. As Silberfein argued when reflecting on the case of Sierra Leone, conflict in such states "bears a close resemblance to criminal activity" enmeshed in "complex criminal networks". ${ }^{51}$ However, perhaps more importantly, she also notes that such conflicts "have expanded with the process of globalization" and as "[i]nternational trade has reached ever more widely into isolated pockets to find the raw materials needed to maintain high levels of industrial production". ${ }^{52}$ The same can be seen in the ongoing and ever intensifying penetration of 'frontier' regions by global capital in a process of restructuring motivated by the global financial institutions which scholars such as McMichael, ${ }^{53}$ Sassen ${ }^{54}$ and Verma ${ }^{55}$ argue, enforce "a new paradigm of governance rooted in neoliberal economic norms" which have degraded the state to the benefit of corporate actors and market forces. ${ }^{56}$ Such processes have undermined the ability of states and supra-national institutions to offset the differentials of power and privilege across boundaries (and indeed between continents), while giving free reign to the most pernicious elements of capital accumulation.

And this is where we see the clearest parallel between the mutual dependency of violence and peace within states and their mutual constitution between states within contemporary neo-liberal global order. The very lives lived by privileged citizens of secure Western democracies (with access to resources, technology, food, education, healthcare, transportation, insurance, etc.) is possible (and increasingly more so) only in so far as we benefit from the ability of corporations to access, appropriate, and control the land, labour and resources of those less privileged. There is nothing particularly surprising about this, and indeed different scholars have noted for some time the fundamentally unequal distribution of certain social commodities; such as justice, security,

\footnotetext{
${ }^{50}$ William Reno, Warlord Politics and African States (Boulder, CO: Lynne Rienner Publishers, 1999).

${ }^{51}$ Marilyn Silberfein, 'The Geopolitics of Conflict and Diamonds in Sierra Leone', Geopolitics 9, no. 1 (2004): 214.

52 Ibid, 203.

53 Philip McMichael, 'Land Grabbing as Security Mercantilism in International Relations', Globalizations 10, no. 1 (2013): 47-64.

${ }^{54}$ Saskia Sassen, 'Land Grabs Today: Feeding the Disassembling of National Territory', Globalizations 10, no. 1 (2013): 25-46.

${ }^{55}$ Ritu Verma, 'Land Grabs, Power, and Gender in East and Southern Africa: So, What's New?', Feminist Economics 20, no. 1 (2014): 52-75.

${ }^{56}$ Gearoid Millar, 'Knowledge and Control in the Contemporary Land Rush: Making Local Land Legible and Corporate Power Applicable in Rural Sierra Leone. Journal of Agrarian Change 16, no. 2 (2016): 209.
} 
development, and peace. In response to the US invasion of Afghanistan in 2001, for example, Roy lamented how "infinite justice for some means infinite injustice for others" ${ }^{57}$ while Duffield described the fundamental differences between development in Western democracies based on strong state provision of social insurance and the "sustainable development" of "self-reliance" 58 allotted to the "surplus population", "waste-life", or "human debris" elsewhere. ${ }^{59}$ Highlighting the complex nature of this operation, both of these authors articulate how a range of systems - discursive, normative, financial, political, military, technological, humanitarian, etc. - collaborate without conscious direction but function nonetheless to pool influence, resources and privilege towards the West. As Keen argued, citing Orwell, "certain kinds of regimes may thrive of enemies and perpetual war. ${ }^{60}$

Keen's work, along with that of many scholars in recent years such as Reno, ${ }^{61}$ Nordstrom, ${ }^{62}$ De Waal, ${ }^{63}$ and others, ${ }^{64}$ has instructed us to think more carefully about how power and priorities flow, via the ever expanding and yet ever tightening web of capitalist reformation, extraction and exchange, across the globe; what Wiuff Moe describes as "globalized political rentier marketplace". 65 These innumerable interactions between countless actors are often framed discursively as positive for all involved. Those who defend the liberal peace model argue, for example, that only open market reforms can provide the "longer-term strategies of economic diversification and poverty reduction" that sustainable peace requires ${ }^{66}$ and an emerging "Business for Peace" literature argues that private industry can play a positive role in post-conflict contexts. ${ }^{67}$ These arguments assume that the entrance of private industry and profit motivated activity will benefit local society and strengthen governance.

\footnotetext{
${ }^{57}$ Arundhati Roy, 'War is Peace,' Outlook Magazine October 29 (2001): 18.

58 Mark Duffield, Development, Security, and Unending War: Governing the World of Peoples (London: Polity Press, 2007), 49.

59 Ibid, 9.

${ }^{60}$ David Keen, Endless War? Hidden Functions of the "War on Terror" (London: Pluto Press, 2006), 52.

${ }^{61}$ Reno, Warlord Politics

${ }^{62}$ Carolyn Nordstrom, Shadows of War: Violence, Power, and International Profiteering in the Twenty-First Century (Berkeley, CA: University of California Press, 2004).

${ }^{63}$ Alex De Waal, The Real Politics of the Horn of Africa: Money, War and the Business of Power (Cambridge: Polity Press, 2015).

64 See also Dawn Paley, 'Drug War as Neoliberal Trojan Horse', Latin American Perspectives 204, no. 42 (2015): 109-132; David Maher, 'The Fatal Attraction of Civil War Economies: Foreign Direct Investment and Political Violence, A Case Study of Colombia', International Studies Review 17 (2015): 217-248; Timothy Raeymaekers, Violent Capitalism and Hybrid Identity in the Eastern Congo: Power to the Margins (Cambridge: Cambridge University Press, 2014).

65 Wiuff Moe, 'The Strange Wars', 117.

${ }^{66}$ Karen Ballentine, 'Conclusion', in The Political Economy of Armed Conflict: Beyond Greed and Grievance, ed. Karen Ballentine and Jake Sherman (Boulder, CO: Lynne Rienner Publishers, 2003), 280; see also Doyle, 'Three Pillars'; Paris, 'Saving Liberal Peacebuilding'.

${ }^{67}$ Timothy L. Fort and Cindy A. Schipani, 'An Action Plan for the Role of Business in Fostering Peace', American Business Law Journal 44, no. 2 (2007): 359-77; Timothy L. Fort, 'Peace through Commerce: A Multisectoral Approach', Journal of Business Ethics 89 (2010): 347-50; Jennifer Oetzel, Michelle Westermann-Behaylo, Charles Koerber, Timothy L. Fort, and Jorge Rivera, 'Business and Peace: Sketching the Terrain', Journal of Business Ethics 89 (2010): 351-373.
} 
But within the contexts of fragility, inequality, and endemic violence characteristic of post-conflict societies these benefits are rarely realized and unpredictable negative effects are far more common, as has been evidenced in cases such as Iraq, ${ }^{68}$ Nigeria, ${ }^{69}$ Brazil,${ }^{70}$ Colombia,,${ }^{71}$ and Sierra Leone. ${ }^{72}$ Such cases show how what we have today is not a global marketplace where equally empowered actors meet to exchange goods and services freely under the equal protection of representative institutions, but a global system of multiple and extreme inequalities giving structure to a complex assemblage of interactions characterized by domination and manipulation. Even when this does not produce direct violence (and it very often does), this can be described, at best, as a complex global system of indirect violence in which peacebuilders are forever swimming against the stream, trying to build peace with projects and programs specific to one field and within individual post-conflict settings.

\section{Complex Systems Theory}

The problem, therefore, is clear. Peacebuilders are always attempting to build peace amidst a complex global system in which violence is an emergent process. Even when a peace agreement has been signed, when direct political violence has come to an end, and a "negative peace" adheres, the global order in which we live is one of pernicious systemic inequality (indirect violence) across multiple axes (political, economic, social, cultural, discursive, technological, etc.) which functions to legitimate this inequality (cultural violence) and very often to spur explicit conflict and direct violence. In our drive in the last decade, clearly necessary as it was, to concentrate more on local actors, settings, and cultures, we have failed to also retain focus on the structures within which we are operating, to acknowledge indeed that specific local or even national policies, projects, and practices are always of limited potential within a complex global system and, in fact, that they may be derailed by the functions of that system. ${ }^{73}$ Visoka has recently noted, for example, how peacebuilding's operation within complex systems display constant cycles of failure and success, ${ }^{74}$ and how they are characterized by an "unpredictable flow of developments that guide" their success and failure. ${ }^{75} \mathrm{In}$

\footnotetext{
${ }^{68}$ Benjamin Tkach, 'Private Military and Security Companies, Contract Structure, Market Competition, and Violence in Iraq,' Conflict Management and Peace Science 36, no. 3 (2019): 291-311.

${ }^{69}$ Isidor A. Udoh and Matthew S. Ibok, 'Manipulative and Coercive Power and the Social-Ecological Determinants of Conflict in the Niger Delta of Nigeria', African Conflict and Peacebuilding Review 4, no. 1 (2014): 60-94.

${ }^{70}$ Noemi Porro and Joaquim Shiraishi Neto, 'Coercive Harmony in Land Acquisition: The Gendered Impact of Corporate 'Responsibility' in the Brazilian Amazon', Feminist Economics 20, no. 1 (2014): 227-248.

71 Nazih Richani, 'Multinational Corporations, Rentier Capitalism, and the War System in Colombia', Latin American Politics and Society 47, no. 3 (2008): 113-144.

72 Gearoid Millar, 'Local Experience of Liberal Peace: Marketization and Emerging Conflict Dynamics in Sierra Leone', Journal of Peace Research 53, no. 4 (2016): 569-581.

73 See Oliver Richmond, 'Peace and the Formation of Political Order', International Peacekeeping 26, no. 1 (2019): 97; Jackson, 'Post-Liberal Peace': 8.

${ }^{74}$ Gezim Visoka Peace Figuration after International Intervention: Intentions, Events and Consequences of Liberal Peacebuilding (London: Routledge, 2016), 2.

75 Ibid, 8.
} 
this sense, peacebuilding, like any complex process, is characterized as much by the unintentional, the uncontrollable, and the unpredictable as it is by intention and agency. ${ }^{76}$

Complexity, therefore, becomes central to any efforts to understand how global systems (which encapsulate all of the sub-scales; regional, international, national, and local) generate violence of different kinds and how peacebuilders operate within such systems. Conflict and peace scholars have noted this complexity for at least 20 years. Some have described conflict situations as "complex political emergencies", ${ }^{77}$ while others have accurately described international interventions in response to many violent situations as "complex peace operations". ${ }^{78}$ However, the full implications of this complexity are rarely acknowledged and these uses of the term do not usually engage substantially with the ideas central to complex systems theory. Appreciating the implications of complexity for peace scholarship, therefore, requires that we re-theorize conflict, peace, transition, and social relations in post-conflict contexts more generally across scales: global, regional, international, national, and local. We must recognize that within such complexity violence and peace emerge from diverse interacting processes often outside the scope of our analyses (whether theoretically, temporally or geographically) and we must bring such processes more into focus. Doing so, however, requires fluency with complex systems theory and its implications for peace theory. Specifically, scholars must come to understand the notions and implications of non-linear causal relationships, positive and negative feedback mechanisms, and organic emergence via selforganization.

Of central interest to peace scholars should be the distinction between complicated and complex systems. Complicated systems may appear opaque and difficult to understand, but are nonetheless characterized by linear and predictable relationships between the operations of their individual components. The many interrelated components of an engine or a computer may make them difficult for the lay user to understand, but their components do interact in a linear and predictable fashion and they are designed by experts with the requisite knowledge to make their functioning predictable. Such systems are defined by the predictable operation of each component part and the linear cause-effect relationships between those components. Importantly, such systems also stop functioning if and when a part is broken or removed (an engine missing a fan belt or a computer missing its CPU, for example). A complex system, on the other hand, cannot be understood by describing the operation of its component parts or the relationships between those parts, and

\footnotetext{
${ }^{76} \mathrm{lbid}, 32$.

77 Jonathan Goodhand, 'From Wars to Complex Political Emergencies: Understanding Conflict and PeaceBuilding in the New World Disorder', Third World Quarterly 20, no. 1 (1999): 13-26; Tom Woodhouse, 'The Gentle Hand of Peace? British Peacekeeping and Conflict Resolution in Complex Political Emergencies', International Peacekeeping 6, no. 2 (1999): 24-37; David Keen, Complex Emergencies (Cambridge: Polity Press, 2008).

78 United Nations, Comprehensive Review of the Whole Question of Peacekeeping Operations in All Their Aspects, A/69/455/Add.1 (New York, NY: United Nations, 2000); Robert A. Rubinstein, 'Cross-Cultural Considerations in Complex Peace Operations', Negotiation Journal 19, no. 1 (2003): 29-49.
} 
damaging or removing one component will not "break" the system as a whole. Instead, complex systems adapt to such changes; the interactions and relationships between components "shift and change, often as a result of self-organization", which produces emergent properties. ${ }^{79}$ As a result, such systems are often described as "complex adaptive systems", which highlights why they cannot be designed and built in order to function in a particular way, but instead function in a particular way as a result of the components organizing themselves "into well-formed structures that are no part of any single agent's intention". 80

A key mechanism by which such self-organization functions is the feedback loop. This is a signalling mechanism by which information is transferred between components of the system in such a way as to either escalate or de-escalate a trend in the system. Signals that lead to escalating trends are called 'positive' feedback loops. We might think, for example, of a crowd of unrelated individuals converging on a downtown area for a few drinks on a Friday night and looking for a fun bar. The louder the bar the more attractive it is to each individual, so the more people try to go in, the busier the bar gets, the more people are attracted. This is a positive feedback loop in that it is the energy and noise created by a large crowd which inspires more people to add to the noise. The same is true for empty bars, the lack of energy and noise leads individuals to wander on looking for a better bar, thus escalating the trend towards quiet. Both are positive feedback loops and show the tendency for such feedback loops to lead to extremes, or cascades. On the other hand, 'negative' feedback loops lead to more sustainable equilibria. Consider, for example, another group of unrelated individuals looking for a quiet café to work on writing a paper. The busier each café is, the less likely each person is to enter, and so the more disbursed the crown becomes among the available cafés. Such a negative feedback loop leads not to the extremes of a few very loud cafes, but to an even distribution of the crowd.

Importantly, these distributions is not planned or designed. They emerge from the system and the independent decisions of the component parts. As Sanderson notes, such structure is the "product of human intention but it is not an intended project". ${ }^{81}$ While each actor in the above examples is motivated by their own individual intention, the eventual distribution of the crowd as a whole is not intended by any of them, nor all of them. This structure is as an emergent property of a complex system. Understanding such dynamics it is of pivotal importance when we consider how violence and peace are mutually constitutive because, counter-intuitively, $t$ need not be the end goal of any particular actor to have a system (either domestically or internationally) in which the privileges of some actors or groups are dependent on the marginalization or disempowerment of others. Intent is not necessary. Systems function in ways unintended by any of the agents involved in those systems.

\footnotetext{
79 Paul Cilliers, Complexity and Postmodernism: Understanding Complex Systems (London: Routledge, 1998), ix. 80 John H. Miller and Scott E. Page, Complex Adaptive Systems: An Introduction to Computational Models of Social Life (Princeton, NJ: Princeton University Press, 2011), 4.

${ }^{81}$ Stephen K. Sanderson, Social Transformations: A General Theory of Historical Development (Lanham: Roman \& Littlefield, 1999), 399.
} 
Indeed, they may function in ways counter to the intent of all actors. In trying to understand how peacebuilding functions within this era of globalized capital, therefore, complex systems theory instructs us to learn to see how peacebuilding projects interact; a) with each other, b) with the diverse array of norms and processes already existing within the society into which they are imposed, and ( perhaps most importantly), c) with the broader regional and global assemblage of norms, institutions and mechanisms of which they are a result and within which they are nested.

The case of Sierra Leone can be used once more to illustrate these complex interactions. It has been noted, for example, that the many projects of intervention in this case interacted in a complex manner to undermine their intended individual and collective impact. In the imaginations of local actors the processes and intentions of many different interventions by different actors became confused, which resulted also in confused expectations in the local population. This confusion, in turn, served to undermine the local experiences of each of the processes applied. ${ }^{82}$ Such interactions among projects gives new credence to older concerns regarding the 'coordination problem' in peace intervention, ${ }^{83}$ and highlight the problems that can emerge when projects interact unpredictably with each other within specific socio-cultural contexts. Indeed, various studies in the case of Sierra Leone have focused on such unpredictable interactions between interventions and the existing social norms and processes. Matsumoto, for example, showed how the post-conflict educational reforms ostensibly implemented as part of the peacebuilding agenda - failed largely because they saw education as an isolated system, and not as nested within broader socioeconomic dynamics ${ }^{84}$ while recent work by Palliere and Cochet brilliantly examined the intricate ways that post-conflict economic development projects have interacted problematically with existing rural social relations. ${ }^{85}$

Such findings are mirrored in work regarding the problematic interaction of post-conflict interventions with traditional patrimonial traditions, ${ }^{86}$ and predominant gender norms,${ }^{87}$ research which also helps illustrate the third and perhaps most concerning complex interaction; that between specific peace interventions and the broader regional and global assemblage of norms, institutions and mechanisms of which they are a result and within which they are nested. Work regarding the Truth and Reconciliation Commission for Sierra Leone, for example, has illustrated the manner in which

\footnotetext{
82 Gearoid Millar, 'Expectations and Experiences of Peacebuilding in Sierra Leone: Parallel Peacebuilding Processes and Compound Friction', International Peacekeeping 20, no. 2 (2013): 189-203.

${ }^{83}$ Roland Paris, 'Understanding the "Coordination Problem" in Postwar Statebuilding,' in The Dilemmas of Statebuilding: Confronting the Contradictions of Postwar Peace Operations, ed. Roland Paris and Timothy Sisk (London: Routledge, 2009), 53-78.

${ }^{84}$ Mitsuko Matsumoto, 'Expectations and Realities of Education in Post-Conflict Sierra Leone: A Reflection of Society or a Driver of Peacebuilding?' in Education, Conflict and Development, ed. Julia Paulson (Oxford: Symposium Books, 2011), 119-144.

${ }^{85}$ Augustine Palliere and Hubert Cochet, 'Large Private Agricultural Projects and Job Creation: From Discourse to reality. Case Study in Sella Limba, Sierra Leone,' Land Use Policy 46 (2018): 422-431.

${ }^{86}$ Rosalind Shaw, 'Memory Frictions: Localizing the Truth and Reconciliation Commission in Sierra Leone', The International Journal of Transitional Justice 1, no. 2 (2007): 183-207.

${ }^{87}$ Caitlyn Ryan, 'Large-Scale Land Deals in Sierra Leone at the Intersection of Gender and Lineage', Third World Quarterly 39, no. 1 (2018): 189-206.
} 
this mechanism was problematic within the local setting because it was an inappropriate projection of global norms of justice into a local socio-cultural milieu that was antagonistic to such processes. ${ }^{88}$ Similarly, large-scale development projects have inappropriately projected global economic and social norms (here we might more appropriately say 'Western' economic and social norms) into rural Sierra Leone, assume that such norms are globally applicable. ${ }^{89}$ But the evidence appears to show that such assumptions far too often misunderstand the reality on the ground and result in negative outcomes for local actors.

Indeed, grounded, local level studies consistently exhibit both the unpredictable relationships between distinct interventions within specific contexts, and the consistent and repeating pattern of disconnect between imported norms and practices and the norms and expectations operative within those contexts; dynamics which have been previously explored in the literature cited above regarding 'hybridity'90 and 'friction'. ${ }^{91}$ Perhaps more critically, however, such problems also evidence the ongoing reliance (normative, financial, and practical) of peace work on the broader global system which privileges certain legitimating logics and specific powerful actors and institutions to the detriment of others, ${ }^{92}$ or, to rephrase that, which protects the privileges and peace of some at the expense of others. The key point is that these privileged legitimating logics are what animates the global context of inequality, marginalization, and disempowerment that prompts violence; in its cultural, indirect, and eventually also direct forms. ${ }^{93}$ As a result, understanding and then having even a hope of successfully building peace requires not only a focus on contexts, on projects, on local experiences, or even on local conceptions of peace, justice, development and 'the good', but also on the broader structures of global violence that define and normalize the logics that adhere today at the global and international scales.

\section{Trans-Scalar Peace Systems}

The great challenge with identifying the problems of peacebuilding as rooted in a complex global conflict system that is serving to legitimate, replicate and implement peace interventions that are reliant on inapplicable and unfamiliar logics in sensitive post-conflict settings, however, is that resolving the problem seems to require new logics, alternative perspectives and, eventually, some

\footnotetext{
${ }^{88}$ Gearoid Millar, 'Performative Memory and Re-Victimization: Truth-Telling and Provocation in Sierra Leone', Memory Studies 8, no. 2 (2015): 242-254.

89 Millar, 'Local Experiences of Liberal'.

90 Mac Ginty, 'Hybrid Peace'; Belloni, 'Hybrid Peace Governance'; Millar, 'Disaggregating Hybridity'.

${ }^{91}$ Annika Björkdahl and Kristine Höglund, 'Precarious Peacebuilding: Friction in Global-Local Encounters', Peacebuilding 1, no. 3 (2013): 289-99; Gearoid Millar, Jair Van der Lijn, and Willemijn Verkoren, 'Peacebuilding Plans and Local Reconfigurations: Frictions between Imported Processes and Indigenous Practices', International Peacekeeping 20, no. 2 (2013): 137-43.

92 See Campbell, Chandler and Sabaratnam, 'A Liberal Peace?'; Michael Pugh, Neil Cooper, and Mandy Turner, Whose Peace? Critical Perspectives on the Political Economy of Peacebuilding (New York, NY: Palgrave MacMillan, 2011).

${ }^{93}$ See also Jackson, 'Post-Liberal Peacebuilding': 4.
} 
means by which to promote and fund new forms of peace. And, indeed, efforts to develop such alternative perspectives figure prominently in work regarding the local turn, ${ }^{94}$ the ethnographic turn, ${ }^{95}$ and everyday peace. ${ }^{96}$ But each of these, whether intentionally or not, has directed attention away from the global system and focused it more on to the national, local, or everyday within post-conflict settings. On the other hand, while publications on hybridity, friction, and scalar peacebuilding have attempted to analyse how the global, national, and local interact, in their efforts to counterbalance the power of the international they have both over-emphasized the agency of the local (inadvertently suggesting a false equality between the global and the local), and largely failed to fully acknowledge and deal with the complex nature of the global system of violence in which they are nested.

Much as is suggested by Richmond's more recent work on "Peace Formation", ${ }^{97}$ any efforts to conceive of peacebuilding which might overcome the violence of this global conflict system must try to find a balance; they must accept that logics and perspectives from the bottom-up are necessary, while recognizing also that the global conflict system structures from the top-down the prevailing context of all peace interventions. To accomplish the first task, a trans-scalar peace system, even when refocusing substantial attention back to the macro-system, must still take seriously the lessons of the local turn. Any such system must necessarily avoid privileging in esteem the norms, paradigms or legitimating logics operative at the global or international scales. This includes the logics of individualism and capitalism which claim universality today and dominate the globalized economic order focused on here, but the list of such operative logics is long and different concepts have been taken as globally applicable for the various interventionary projects that are applied in post-conflict societies. This includes all of those legitimating and motivating logics that govern interventions for the purpose of peace, security, justice, and development processes.

Consistent with recent literature, therefore, the first step in developing a global peace system would in fact be to learn well the lessons of the local turn and direct substantial attention to understanding alternative logics on the ground in post-conflict contexts and to question, critique, and abandon - or at the very least put serious effort into rethinking - those logics that are inapplicable at the scale of implementation (no matter how deeply felt their "universal" nature). This, in turn, requires robust critical efforts at inter-disciplinary and trans-disciplinary thinking, as well as the incorporation of a much more varied set of actors and institutions in the development of post-conflict interventions; including regional, national and local actors with little or no "expertise" in

\footnotetext{
${ }^{94}$ Mac Ginty and Richmond, 'The Local Turn'.

95 Roger Mac Ginty and Oliver P. Richmond, 'The Fallacy of Constructing Hybrid Political Orders: A Reappraisal of the Hybrid Turn in Peacebuilding', International Peacekeeping 23, no. 2 (2016): 223; Gearoid Millar, An Ethnographic Approach to Peacebuilding: Understanding Local Experiences in Transitional States (London: Routledge, 2014).

${ }^{96}$ Richmond, 'Becoming Liberal'; Richmond and Mitchell, 'Hybrid Forms of Peace'.

97 Oliver P. Richmond, Peace Formation and Political Order in Conflict Affected Societies (New York, NY: Oxford University Press, 2016).
} 
peacebuilding. Such an approach requires, in essence, a wholesale decentring of the usually dominating peace industry institutions and the norms by which they are governed. In short, the first step and primary move towards a global peace system is very much aligned with previous recommendations from each of the 'turns' noted above (the spatial, local, everyday, ethnographic, etc.), and the idea of a global peace system should not in any way be seen to contradict, but instead should build upon, this earlier work.

The second step - perhaps both more fundamental and more extreme - is to take seriously the complex systemic nature of conflict, violence and peace in the contemporary globalized environment and, thus, to recognize that even the local turn must be set within the context of this pervading global system which is today inherently violent in varying ways (cultural, indirect, and direct) and which has led to the mutual constitution of violence and peace within and between states. Scholars who have been writing about hybridity, friction and scalar peacebuilding are clearly attempting to analyse motivations, policies, practices, impacts and actors across scales, and those works both point in the right direction and hint at the complex dynamics by which actors and institutions engage in peacebuilding in the contemporary world. However, none of these works capture appropriately the interrelatedness and multidimensionality of the feedback loops (positive and negative) within and between scales and thus the elegant, fluid, and organic self-organization inherent to the complex system which forms the context of peacebuilding interventions and, ironically (in its very fluidity and apparent naturalness), serves to hide from analysis its social construction. In failing to appreciate the emergence inherent in the system, such approaches fail to recognize the greatest challenge to peacebuilding (the manner in which systems function free of the intent of its constitutive agents) and, at the same time, miss one of the primary paths forward for the field; an attempt to harness this emergence for the proliferation of new legitimating logics of peace.

In other words, by acknowledging that peacebuilding is today always conducted amidst violence, we can both recognize the depth of the problems we face (in that we can see that the global system of violence is self-organized and beyond the intentional control of any specific actors or institutions) and become aware of a potential route towards a new approach (reshaping the legitimating logics). This new approach, therefore, must be one that deconstructs the complex global conflict system by attacking and undermining its apparent universality and claim to truth at every turn. A system in which "infinite justice for some means infinite injustice for others" is not and cannot ever be a just system. ${ }^{98} \mathrm{~A}$ system in which the insured development of the privileged West is bought at the expense of the "waste life" in the rest of the world is not and cannot ever be a peaceful system? ${ }^{99}$ Such a system is conflictual and violent in its very nature. As a result, the second step to constructing a new system is to tear relentlessly at the legitimating logics of the current system. We

\footnotetext{
${ }^{98}$ Roy, 'War is Peace', 18.

${ }^{99}$ Duffield, Development, Security and Unending War, 49.
} 
must critique and call into question every effort to normalize and reproduce such legitimating discourses and constantly forward robust competing discourses.

The third step must be to fundamentally redefine what is acceptable in the design, funding, incentivization and administration of peacebuilding practice. To reflect once more on the case of Sierra Leone, as articulated above, the TRC, educational reforms, and large development projects (just a few of the many interventions applied) were attempting to build peace within a society still riven by structural violence ${ }^{100}$ (and failed as a result). As has been true in other cases as diverse as the Democratic Republic of Congo, ${ }^{101} \mathrm{Nepal},{ }^{102}$ and Indonesia, ${ }^{103} \mathrm{few}$ of these projects were designed or implemented with the needs of the majority of local actors as the priority, nor with sufficient understanding of locally dominant conceptions of peace, justice, development or security. For those reasons the projects implemented had little chance of contributing predictably to those vaunted end goals. In other words, combining these two practical failures meant that these projects tended not to remedy but to exacerbate the indirect violence endemic to the setting. As a result, sustained efforts at empirical analysis of the failures of peacebuilding endeavours of this sort, combined with a forceful and articulate presentation of alternative logics which might underpin peacebuilding processes within a trans-scalar peace system, may together serve to both undermine what is normal today and provide a foundation for a more just and peaceful system in the future.

The fourth step is to recognize and accept that we cannot control complex systems, but nor are we powerless to shape the energies that feed into them so as to work incrementally towards our preferred outcomes. ${ }^{104}$ Recognizing the self-regulating nature of complex systems and the emergent processes that result could easily drive us towards a cynical fatalism in which we give up on good intentions and the normative agenda of peace and conflict studies as a field. After all, if the complex nature of the system means that the aggregate function of the best of intentions may be a negative result, then is it not best to avoid intervening at all ${ }^{105}$ But we can do better than such cynicism and fatalism if we learn to monitor and evaluate the implementation and impact of peacebuilding projects both at the micro (specific project) and the macro (aggregate impacts) levels and with a frequency and consistency that allows for iterative alterations to our practices. In order to avoid the over-bureaucratic and top-down management we have already critiqued, this would also imply that we have to

\footnotetext{
${ }^{100}$ Rosalind Shaw, 'Linking Justice with Reintegration? Ex-Combatants and the Sierra Leone Experiment', in Localizing Transitional Justice: Interventions and Priorities After Mass Violence, ed. Rosalind Shaw, Lars Waldorf and Pierre Hazan (Stanford: Stanford University Press, 2011), 111-132.

${ }^{101}$ Autesserre, Peaceland;

102 Simon Robins, 'Constructing Meaning from Disappearance: Local Memorialisation of the Missing in Nepal', International Journal of Conflict and Violence 8, no. 1 (2014): 104-118.

103 Birgit Brauchler, The Cultural Dimension of Peace: Decentralisation and Reconciliation in Indonesia (Basingstoke: Palgrave MacMillan).

${ }^{104}$ See Jackson, 'Post-Liberal Peacebuilding': 12.

105 See Pol Bargues-Pedreny and Elisa Randazzo, ‘Hyrbid Peace Revisited: An Opportunity for Considering SelfGovernance,' Third World Quarterly 39, no. 8 (2018): 1543-1560.
} 
significantly downsize both the extent of our interventions and our ambitions for them and hand much of the decision making and implementation power to local actors, much as de Coning has recently argued. ${ }^{106}$ But this too would be positive. In short, fully recognizing and accepting that peacebuilding is always occurring in complex trans-scalar systems seems inherently and implicitly to demand not that we refocus again on the global to the detriment of the local, but that we really implement the lessons of the local turn in order to undermine the most pernicious effects of the global conflict system.

\section{Conclusion}

The goal of this paper has been to consider the implications of peacebuilding within contexts of violence. The paper was initially going to be an assessment of how specific peacebuilding projects were implemented within (and eventually failed because of) the indirect violence of post-conflict Sierra Leone. However, while writing it became clear that these failures were not really the result of the dynamics within Sierra Leone, but were more accurately described as symptomatic of a complex global conflict system legitimated by dominant Western logics which, while claiming universality, have motivated great violence across much of the world. The paper, therefore, instead sought to bring together disparate arguments within the literature which have not yet been tied together. I described how violence and peace are mutually constitutive both within states and in the global system, and then presented some of the literature from the last 20 years which makes this argument quite explicit. I then presented a brief discussion of complexity theory and the manner in which the mutual constitution of violence and peace are emergent processes disconnected from any explicit intentions among the component actors and institutions.

The final section argues that this recognition demands that we try to restructure this global conflict system (and all of its component dynamics; normative, discursive, legal, institutional, practical) into a global peace system. While I recognize the audacity of such a goal, I am unsure what alternative options there are, other than technocratic interjections at the margins of the problem which will not serve to actually reform the system (i.e. to continue with business as usual). In conclusion, therefore, I presented four potential steps which might help us start on this project of construction a global peace system. These steps are:

1) A constant critique of the privileged legitimating logics that dominate the global system today and a robust articulation and defence of alternative logics

2) The acceptance and rigorous implementation of the lessons of the local turn (specifically more diverse inclusion in the theory, design, and implementation of peacebuilding efforts)

3) An effort to harness the power of emergence via constant and consistent monitoring and evaluation of micro (project) and macro (aggregate) level impacts of peace interventions

${ }^{106}$ See Cedric De Coning, 'Adaptive Peacebuilding,' International Affairs 94, no. 2 (2018): 301-317. 
4) The iterative reformulation of peace interventions in response to their emerging characteristics and impacts in the service of sustainable peace 